\title{
Literatur Review
}

\section{Hypolipidemic Effects Of Aloe Vera (Aloe Vera L.)}

\section{Roy Sukbir Singh ${ }^{1}$, Hendrika A Silitonga ${ }^{2}$}

1. Student of Masters Program in Biomedical Sciences, Faculty of Medicine, Universitas Methodist Indonesia, Medan

2. Department of Histology, Faculty of Medicine, Universitas Methodist Indonesia, Medan

* Correspondence: e-mail: roydhillon53@gmail.com

\section{Abstract}

Background: Chronic hyperlipidemia is a trigger factor for serious diseases, one of which is atherosclerosis. Lipid profile disorders in the form of increased total cholesterol, LDL and decreased HDL levels are believed to be one of the major triggering factors for cardiovascular disease. One of the treatments for hyperlipidemia in addition to using conventional therapy can also be with traditional treatments such as aloe vera (Aloe Vera L). The content of glucomannan in aloe vera is believed to act as a hypolipidemic agent. Method: This paper uses a literature study or literature review of research articles. Search articles through Google Scholar and Pubmed with keywords used hypolipidemia and Aloe vera. The criteria for the articles used were published in the last 5 years, namely from 2016 to 2021. Results: Based on the literature search, there were 8 studies related to the effect of aloe vera on lipid profile levels, of which there were 7 studies on experimental animals and 1 study on humans. Aloe vera used varies from extract form, gel and powder form in capsules. Conclusion: Based on the literature study, it was found that aloe vera is an herbal plant that has a fairly effective hypolipidemic effect.

Keywords: Hypolipidemic, Aloe Vera L 


\section{INTRODUCTION}

Chronic hyperlipidemia is a trigger factor for serious diseases, one of which is atherosclerosis. Lipid profile disorders in the form of increased total cholesterol, LDL, and decreased HDL levels are believed to be one of the major triggering factors for cardiovascular disease. [1]

The leading cause of death in the adult population in the United States is cardiovascular disease. Patients with hyperlipidemia have twice the risk of suffering from CVD (cardiovascular disease) than those who have normal cholesterol levels. [2]. In the United States, more than 100 million adults, or about $53 \%$ have elevated LDL levels and about 31 million adults have total cholesterol levels exceeding $240 \mathrm{mg} / \mathrm{dl}$. [1]According to $\mathrm{WHO}$ in 2008, the prevalence of hyperlipidemia in Southeast Asia was around 30.3\%, which is lower than the incidence in Europe (53.7\%) and America (47.7\%). In Indonesia, the prevalence of hyperlipidemia in adults aged 25 years is around $36 \%$, of which $33.1 \%$ in men and $38.2 \%$ in women. The prevalence of cardiovascular disorders related to hyperlipidemia in Indonesia is around $37 \%$.[3][4]

One of the treatments for hyperlipidemia is lifestyle modification with exercise and a low- fat diet. If these efforts fail, it is necessary to consider starting the use of drugs that function to lower blood lipids.[5] Statins are the first-line drugs for hypercholesterolemic patients because they are effective monotherapy in hyperlipidemia with comorbid coronary heart disease. However, statins have the main effect on myalgia (muscle pain or muscle weakness), especially when used in combination with fibrates [5][6]. There are side effects from conventional treatment so that complementary therapy is needed in dealing with hypercholesterolemia, which is derived from natural ingredients that are relatively safe and easy to cultivate, one of which is found in aloe vera (Aloe vera L.).[7]

Aloe vera (Aloe vera L.) is a plant that is widely used for various nutritional products, pharmaceutical products, and cosmetics. The pharmacological effects of Aloe vera $\mathrm{L}$ include: antitumor, anti-inflammatory, antiviral, anxiolytic, hypolipidemic, hypoglycemic, antiatherogenic, antifungal, antioxidant, anti-bacterial, nephroprotective, and helps wound healing.[7]The biologically active substances contained in Aloe vera L. are more than 200 kinds. This plant is rich in anthraquinones/anthrones, vitamins, amino acids, plant sterols (campestrol, cholesterol, -sitosterol), 
and polysaccharides. Types of polysaccharides contained in Aloe vera L. including glucomannan which has excellent properties in absorbing bile acids and will be carried out with feces, as a result, the cholesterol bound by the glucomannan fiber does not enter the blood vessels. Glucomannan also accelerates the degradation of the enzyme HMG-CoA reductase so that the conversion of mevalonate to cholesterol is inhibited. [8]

\section{METHODS}

\section{Study Design}

This research is a research using literature study method or literature review. A literature review is a comprehensive overview of the research that has been done on a specific topic to show the reader what is already known about the topic and what is not known, to seek rationale from research that has been done or for further research ideas.

The data used in this study comes from the results of research that has been carried out and published in national and international online journals. In conducting this research, the researchers searched for research journals published on the internet using the Google Schoolar and PubMed search engines.The keywords used in the search areHypolipidemic, Aloe Vera

\section{Population and Sample}

This study uses a literature study where Google Scholar and Pubmed search engines are used.From the search results, 20 articles were identified, but only 8 journals entered the criteria and were discussed in this study. Inclusion and exclusion criteria can be seen in table 1 .

\section{Study Variabel}

The dependent variable in this study was hyperlipidemia while the independent variable was aloe vera extract (Aloe Vera L).

\section{Operational Definition of Varia- bles}

Hyperlipidemia is a lipid metabolism disorder characterized by increased levels of total cholesterol, LDL cholesterol, triglycerides and/or decreased levels of HDL cholesterol.In the process of atherosclerosis, everything has an important role and is very closely related to one another.

Aloe vera is a plant native to Africa, specifically Ethiopia, which belongs to the Liliaceae group.Aloe vera plant is known to have many uses such as anti-inflammatory, antifungal, antibacterial, and cell regeneration and is believed to have a hypolipidemic effect in the form of extracts, gels and other processed forms. 


\section{Study Instruments}

The strategy used to find articles is using the PICOS framework. Population/problem that is population or problem to be analyzed in accordance with the themes that have been determined in the literature review. Interventionwhich is a management action on individual or community cases as well as an explanation of the management of the study in accordance with the themes that have been determined in the book literature review. Comparisonie intervention or other management used as a comparison, if not there can use the control group in the selected study. Outcome namely the results or outcomes obtained in previous studies that are in accordance with the themes that have been determined in the literature review.

In this study the problem was hyperlipidemic patients, there was no intervention in this study, the comparison in this study was aloe vera, and the expected outcome was the hypolipidemic effect of aloe vera. which then analyzed using the table for analyzed from tree discussion, results from studies so that know the similarities and differences of these journals (Table 2)

\section{Data Analysis}

This research uses literature review method design with identification, evaluation, and interpretation of all research results related to certain topics. Methodliterature review, summarizes the results of primary research in a more comprehensive presentation of facts comprehensive and balanced

\section{Research Ethics}

There is no ethical clearance in this study because it only uses literature study.

Table 1. Inclusion and Exclusion Criteria in Literature Review

\begin{tabular}{|c|c|}
\hline \multicolumn{2}{|r|}{ Inclusion Criteria } \\
\hline Period & $\begin{array}{l}\text { The maximum time for publishing journals is the last } 5 \text { years from } \\
2016 \text { to } 2021\end{array}$ \\
\hline Language & Indonesian and English \\
\hline Subject & Hyperlipidemic Patients \\
\hline Article Type & $\begin{array}{ll}\text { 1. } & \text { Original article } \\
\text { 2. } & \text { Not in abstract form } \\
\text { 3. } & \text { Full-text publication } \\
\end{array}$ \\
\hline Search time limit & $\begin{array}{l}\text { 1. The deadline starts from } 17 \text { July to } 06 \text { August } \\
2021\end{array}$ \\
\hline Search location & $\begin{array}{ll}\text { 1. } & \text { PubMed } \\
\text { 2. } & \text { Google Scholar }\end{array}$ \\
\hline
\end{tabular}




\begin{tabular}{ll}
\hline Keywords & Hypolipidemic, Aloe Vera \\
\hline Article Type & $\begin{array}{l}\text { The research method is not descriptive because researchers need } \\
\text { to identify relationships, not just descriptions. }\end{array}$ \\
\hline Results & $\begin{array}{l}\text { Research results that have been published and must have a p- } \\
\text { value or must be read by statistics because researchers need to see } \\
\text { whether there is a relationship. }\end{array}$ \\
\hline
\end{tabular}

Table 2. Study Description Literature Review

\begin{tabular}{|c|c|c|c|c|}
\hline $\begin{array}{c}\text { Name, Year, } \\
\text { Title }\end{array}$ & Design & Sample & $\begin{array}{l}\text { Measuring } \\
\text { instrument }\end{array}$ & Results \\
\hline $\begin{array}{l}\text { Devi, } 2019 \\
\text { Hypolipidem- } \\
\text { ic effect of } \\
\text { ethanolic ex- } \\
\text { tract of aloe } \\
\text { vera (aloe } \\
\text { vera l) on } \\
\text { male white } \\
\text { rat hypercho- } \\
\text { lesterolemia } \\
\text { model }\end{array}$ & $\begin{array}{l}\text { The research } \\
\text { design uses } \\
\text { laboratory } \\
\text { experiments } \\
\text { with pre and } \\
\text { post-test } \\
\text { methods } \\
\text { with control } \\
\text { group design }\end{array}$ & $\begin{array}{l}\text { The study involved } 25 \\
\text { male white Rattus } \\
\text { norvegicus induced by } \\
\text { a high-fat diet for } 14 \\
\text { days. Subjects were } \\
\text { divided into } 5 \text { groups: } \\
\text { negative control (aqua } \\
\text { dest), positive control } \\
\text { (cholestyramine } \\
0.2 \mathrm{~g} / 200 \mathrm{gBW} / \text { day), Al- } \\
\text { oe vera ethanol extract } \\
\mathrm{L} \text { dose I } \\
(0.3 \mathrm{~g} / 200 \mathrm{gBW} / \text { day), } \\
\text { Aloe vera ethanol ex- } \\
\text { tract } \mathrm{L} \text { dose II ( } \\
0.6 \mathrm{~g} / 200 \mathrm{gBW} / \text { day), eth- } \\
\text { anol extract of Aloe } \\
\text { vera } \mathrm{L} \text { dose III } \\
\text { (1.2g/200gBW/day). } \\
\text { Measurement of lipid } \\
\text { profile levels was car- } \\
\text { ried out on day } 7 \text {, day } \\
21 \text {, and day } 35 \text {. }\end{array}$ & $\begin{array}{l}\text { Rats Lipid } \\
\text { profile kit }\end{array}$ & $\begin{array}{l}\text { The results of the } \\
\text { Shapiro-Wilk test and } \\
\text { the Lavene test showed } \\
\text { that all data groups } \\
\text { were normal and ho- } \\
\text { mogeneous. Paired T- } \\
\text { Test results obtained } \mathrm{p} \\
\text { value }=0.000 \text { for both } \\
\text { triglycerides, LDL cho- } \\
\text { lesterol, and total cho- } \\
\text { lesterol. Furthermore, } \\
\text { the One Way Anova } \\
\text { parametric test results } \\
\mathrm{p}<0.05 \text { for the three li- } \\
\text { pid profiles. LSD test on } \\
\text { triglyceride levels in the } \\
\text { aquades group with } \\
70 \% \text { ethanol extract of } \\
\text { Aloe vera L doses of } \\
0.3 \mathrm{~g} / 200 \mathrm{gBW} / \text { day, } \\
0.6 \mathrm{~g} / 200 \mathrm{gBW} / \text { day, and } \\
1.2 \mathrm{~g} / 200 \mathrm{gBW} / \text { day re- } \\
\text { spectively, } \mathrm{p}=0.012 \text {, } \\
\mathrm{p}=0.000 \text { and } \mathrm{p}=0,000 \text {. } \\
\mathrm{LSD} \text { test on LDL choles- } \\
\text { terol and total choles- } \\
\text { terol in the distilled wa- } \\
\text { ter group with } 70 \% \text { eth- } \\
\text { anol extract of Aloe } \\
\text { vera L only at a dose of } \\
1.2 \mathrm{~g} / 200 \mathrm{gBW} / \text { day } \\
\text { which was significantly } \\
\text { different with } \mathrm{p}=0.006 \\
\text { and } \mathrm{p}=0.001 .70 \% \text { etha- } \\
\text { nol extract of Aloe vera } \\
\mathrm{L} \text { at a dose of }\end{array}$ \\
\hline
\end{tabular}


levels,

\begin{tabular}{|c|c|c|c|c|}
\hline $\begin{array}{l}\text { Prabha } \\
\text { Verma, } 2016 \\
\text { Hypolipidem- } \\
\text { ic Activity of } \\
\text { Aloe Vera in } \\
\text { Hyper- } \\
\text { lipidemic } \\
\text { Mice }\end{array}$ & $\begin{array}{l}\text { Experimental } \\
\text { studies on } \\
\text { experimental } \\
\text { animals }\end{array}$ & $\begin{array}{l}\text { The hypolipidemic ac- } \\
\text { tivity of Aloe vera ex- } \\
\text { tract (Family: Liliaceae) } \\
\text { was studied in two } \\
\text { models of hyper- } \\
\text { lipidemia. First acute } \\
\text { model: hyperlipidemia } \\
\text { was induced by inject- } \\
\text { ing a single dose of tri- } \\
\text { ton WR-1339 } \\
\text { (400mg/kg, BW) intra- } \\
\text { peritoneally in rats then } \\
\text { administration of aloe } \\
\text { vera extract at a dose of } \\
500 \text { mg/kg BW, In the } \\
\text { chronic model, hyper- } \\
\text { lipidemia was induced } \\
\text { by feeding with HFD } \\
\text { rich cholesterol in mice. } \\
\text { Treatment with aloe } \\
\text { vera seed extract (500 } \\
\text { mg/kg BW) for } 15 \text { days. } \\
\text { Hypolipidemic activity } \\
\text { of Aloe vera was com- } \\
\text { pared with the stand- } \\
\text { ard drug guggulipid } \\
\text { ( } 200 \text { mg/kg, BW) in } \\
\text { both models. }\end{array}$ & $\begin{array}{l}\text { Rats Lipid } \\
\text { profile kit }\end{array}$ & $\begin{array}{l}\text { Treatment with aloe } \\
\text { vera extract at a dose of } \\
500 \mathrm{mg} / \mathrm{kg} \text { BW, caused a } \\
\text { decrease in the levels of } \\
\mathrm{TC}, \mathrm{PL} \text {, and TG by } 28 \text {, } \\
25 \text {, and } 26 \% \text {, respective- } \\
\text { ly, along with reactiva- } \\
\text { tion of PHLA by } 22 \% \text {. } \\
\text { Treatment with aloe } \\
\text { vera extract for } 15 \text { days } \\
\text { reversed plasma levels } \\
\text { of TC, PL, and TG by } \\
25,21 \text {, and } 31 \% \text {, respec- } \\
\text { tively, along with reac- } \\
\text { tivation of PHLA by } \\
21 \% \text {. The hypolipidemic } \\
\text { action of aloe vera at a } \\
\text { dose of } 500 \mathrm{mg} / \mathrm{kg} \text { BW } \\
\text { is comparable to that of } \\
\text { guggulipid at a dose of } \\
200 \mathrm{mg} / \mathrm{kg} \text { BW. }\end{array}$ \\
\hline $\begin{array}{l}\text { Imaga, } 2016 \\
\text { Evaluation of } \\
\text { the therapeu- } \\
\text { tic effect of } \\
\text { aloe vera gel } \\
\text { on alloxan- } \\
\text { induced dia- } \\
\text { betes rats }\end{array}$ & $\begin{array}{l}\text { Experimental } \\
\text { studies on } \\
\text { experimental } \\
\text { animals }\end{array}$ & $\begin{array}{l}\text { Rats were divided into } \\
\text { six groups, each group } \\
\text { consisting of six rats. } \\
\text { Then it was induced } \\
\text { with alloxan monohy- } \\
\text { drate ( } 170 \mathrm{mg} / \mathrm{kg} \mathrm{BW)} \\
\text { intraperitoneally after } \\
12 \text { hours of fasting. } \\
\text { Groups I and V similar- } \\
\text { ly received isotonic sa- } \\
\text { line. Diabetes was con- } \\
\text { firmed by fasting blood } \\
\text { glucose (GDP) levels } \\
\text { above } 350 \mathrm{mg} / \mathrm{dl} \text { using } \\
\text { GlucoMetre (AccuChek } \\
\text { Active). Aloe vera Gel } \\
\text { (AVG) extract was ad- } \\
\text { ministered for } 14 \text { days }\end{array}$ & $\begin{array}{l}\text { Rats Lipid } \\
\text { profile kit }\end{array}$ & $\begin{array}{l}\text { The lipid profile } \\
\text { showed increased levels } \\
\text { of total cholesterol (TC), } \\
\text { triglycerides (TG), and } \\
\text { low-density lipoprotein } \\
\text { (LDL) in the diabetes } \\
\text { group that was not } \\
\text { treated compared to the } \\
\text { normal control group } \\
\text { and the group that was } \\
\text { treated with Aloe Vera. } \\
\text { The AVG group } \\
\text { showed a decrease in } \\
\text { the lipid profile and an } \\
\text { increase in HDL levels. }\end{array}$ \\
\hline
\end{tabular}


along with metformin

and alloxan. Blood

samples were taken

from fasting rats to as-

sess the effect of AVG

on biochemical, hema-

tological, oxidative

stress parameters as

well as the histological

examination of the liv-

er, kidneys, and pan-

creas.

Louay, 2019 Test on hu-
Hypoglycemic mans
and Hypoli-
pidemic Effects
Aloe Vera on
Patients with

Type 2 Diabetes
Forty-five patients with

Lipid pro-

type 2 diabetes mellitus file ELISA

participated in this

study. Participants

were divided into 3

groups, each group

consisted of 15 patients.

Group I was given cap-

sules containing AV

$100 \mathrm{mg}$ powder, group

II was given capsules

containing AV 200 mg

powder while group III

was considered as a

control. Glycated he-

moglobin (HbA1C) and

lipid profiles (Total

Cholesterol (TC),

LDL/C, HDL/C, and

triglycerides) were

measured at baseline

and the end of the 12-

week study.

\begin{abstract}
There was a significant
decrease $(p<0.05)$ in the

$\mathrm{HbA} 1 \mathrm{c}$ values in groups

I and II. The reduction

was $11.1 \%$ and $25 \%$ in

groups I and II respec-

tively and the decrease

was not significant

$(p<0.05)$ between the

subjects of group III.

There was a significant decrease $(p \leq 0.05)$ in total cholesterol 6.5\% and $7.11 \%$, triglycerides $10.4 \%$ and $12.6 \%$, Low-

Density Lipoprotein
\end{abstract}

(LDL-C) 7.5\% and

$11.9 \%$, and a significant

increase in High-

Density Lipoprotein

(HDL-C) $8 \%$ and 25\%

was observed in the

subjects of groups I and

II, respectively. The ra-

tio of LDL-C to HDLC

decreased from 3.71 to

3.2 and 3.9-2.7 in group

I and II subjects after

the study, respectively.

\begin{tabular}{|c|c|c|c|c|}
\hline $\begin{array}{l}\text { Autumn, } \\
2017 \\
\text { Hypolipidem- } \\
\text { ic Effects of } \\
\text { Aloe Vera Gel } \\
\text { Extract in } \\
\text { Adult Male } \\
\text { Rats Given a } \\
\text { High-Fat }\end{array}$ & $\begin{array}{l}\text { Experimental } \\
\text { studies on } \\
\text { experimental } \\
\text { animals }\end{array}$ & $\begin{array}{l}\text { In this experimental } \\
\text { study, } 40 \text { adult male } \\
\text { rats were included in } \\
\text { the control group } \\
\text { (without treatment), the } \\
\text { sham group (treated } \\
\text { with a } 10 \mathrm{ml} / \mathrm{kg} \text { high-fat } \\
\text { diet), and three experi- } \\
\text { mental groups receiv- }\end{array}$ & $\begin{array}{l}\text { Rats Lipid } \\
\text { profile kit }\end{array}$ & $\begin{array}{l}\text { The results showed that } \\
\text { a high-fat diet signifi- } \\
\text { cantly increased serum } \\
\text { cholesterol, triglycer- } \\
\text { ides, LDL ( } \mathrm{p}<0.001) \text {, } \\
\text { and weight gain } \\
\text { ( } \mathrm{p}<0.01 \text { ) but did not } \\
\text { significantly affect se- } \\
\text { rum HDL levels. How- }\end{array}$ \\
\hline
\end{tabular}


Diet

$\begin{array}{ll} & \\ & \\ & \\ & \\ & \\ & \\ & \\ & \\ & \\ \text { Ramesh, } & \text { Experimental } \\ \text { Comparative } & \text { experimental } \\ \text { Comaluation of } & \text { animals } \\ \text { Anti-Obesity } & \\ \text { Effects of Aloe } & \\ \text { Vera and } & \\ \text { Gymnema } & \\ \text { Sylvester } & \\ \text { Supplementa- } & \\ \text { tion in Rats } & \\ \text { Given a } & \\ \text { High-Fat } & \\ \text { Diet } & \\ \text { C57BL/6J } & \\ & \\ & \\ & \\ & \\ & \\ & \\ & \\ & \\ & \\ & \end{array}$

ing a high-fat diet $(10 \mathrm{ml} / \mathrm{kg})$ along with 150,300 and $600 \mathrm{mg} / \mathrm{kg}$ aloe vera gel extract. The test was carried out for 60 days. In the end, after being anesthetized, the rat heart phlebotomy was performed and then the serum cholesterol, triglyceride, LDL, and HDL levels were measured. The results obtained were analyzed by ANOVA and Duncan tests

\section{Twenty-four male} C57BL/6J mice (aged 5-

6 weeks) were obtained from the National Institute of Nutrition, Hyderabad (Andhra Pradesh, India). After 1 week of acclimatization, the mice were divided into four groups: control diet, HFD, HFD + AV (1\% w/w) (HFD + $\mathrm{AV})$ and HFD + GS (1\% $\mathrm{w} / \mathrm{w})(\mathrm{HFD}+\mathrm{GS})$, and fed for 12 weeks. At the end of the experiment, different parameters such as body weight, feed intake, organ weight, fasting blood glucose, oral glucose tolerance test, plasma lipid level, and adipocytokine analysis expression were evaluated. ever, in the group receiving Aloe-vera gel and a high-fat diet, there was a significant reduction in body weight and serum cholesterol, triglycerides $(\mathrm{p}<0.05)$, and LDL $(\mathrm{p}<0.01)$ levels.

\section{Rats Lipid At the end of the \\ profile kit experimental period, oral administration of both herbs showed a significant reduction ( $\mathrm{P}$ $<0.05$ and $\mathrm{P}<0.001$ ) in plasma glucose and lipid levels in HFD-fed mice}

\begin{tabular}{|c|c|c|c|c|}
\hline $\begin{array}{l}\text { Rahoui, } 2018 \\
\text { Beneficial } \\
\text { Effects Of } \\
\text { Aloe Vera Gel } \\
\text { On Lipid }\end{array}$ & $\begin{array}{l}\text { Experimental } \\
\text { studies on } \\
\text { experimental } \\
\text { animals }\end{array}$ & $\begin{array}{l}48 \text { male Wistar rats } \\
\text { aged } 4 \text { weeks were } \\
\text { used in this study. Rats } \\
\text { were randomly divided } \\
\text { into two groups with }\end{array}$ & $\begin{array}{l}\text { Rats Lipid } \\
\text { profile kit }\end{array}$ & $\begin{array}{l}\text { Plasma glucose, choles- } \\
\text { terol, and triglyceride } \\
\text { levels were significantly } \\
\text { higher in obese rats } \\
\text { compared to control }\end{array}$ \\
\hline
\end{tabular}




Profile, Lipase
Activity And
Oxi-
dant/Antioxid
ant Status In
Obese Rats

Mandeep,
2018
Improvement
of Diabetes
with aloe vera
in rats In-
duced Diabet-
ic Nephropa-
thy By Impli-
cations Of
Oxidative
Stress And
Hyper-
lipidemia

the same mean weight.

The first group (control, $\mathrm{n}=24)$ was fed a standard diet $(330 \mathrm{~kJ} / 100 \mathrm{~g})$, the second group (obese, $\mathrm{n}=24$ ) was fed the diet for 4 weeks before starting AVG.

After that, the mice in each group ( control or obesity) were divided into three groups after treatment. Control and obesity groups ( $\mathrm{C}$ or $\mathrm{O}$, $\mathrm{n}=8$ ) were orally treated every two days with a physiological solution at $0.9 \% \mathrm{NaCl}(1 \mathrm{ml}$ per mouse) to eliminate any variation due to gavage-induced stress. AVG (100 mg/kg/day) was administered to the Aloe control group (C100: $n=8$ ) and the Aloe Obese group (O100: $\mathrm{n}=8)$. AVG (200 $\mathrm{mg} / \mathrm{kg} /$ day) was administered to the Aloe control group (C200: rats. AVG treatment had no effect in the control group. In obese rats treated with AVG, there was a significant reduction in glucose, triglyceride, and cholesterol levels in obese rats given AVG 100 mg/kg/day. AVG at a concentration of $200 \mathrm{mg} / \mathrm{kg} /$ day restored LDL- and HDL$C$ levels in obese rats to be similar to those in the control group.

\begin{tabular}{|c|c|c|c|}
\hline $\begin{array}{l}\text { Experimental } \\
\text { studies on } \\
\text { experimental } \\
\text { animals }\end{array}$ & $\begin{array}{l}\text { Six groups were em- } \\
\text { ployed in this study } \\
\text { and each group con- } \\
\text { sisted of seven mice. } \\
\text { Group I (normal con- } \\
\text { trol): rats were reared } \\
\text { with standard food and } \\
\text { water and were not } \\
\text { given any treatment. } \\
\text { Group II (diabetic con- } \\
\text { trol): rats were given } \\
\text { STZ ( } 55 \text { mg/kg, i.p., } \\
\text { once) dissolved in cit- } \\
\text { rate buffer (pH } 4.5) \text {. } \\
\text { Group III (Aloe vera): } \\
\text { normal rats were given } \\
\text { Aloe vera ( } 300 \text { mg/kg } \\
\text { po) for seven weeks. } \\
\text { Group IV (Treated with }\end{array}$ & $\begin{array}{l}\text { Rats Lipid } \\
\text { profile kit }\end{array}$ & $\begin{array}{l}\text { Plasma glucose, choles- } \\
\text { terol, and triglyceride } \\
\text { levels were significantly } \\
\text { higher in obese rats } \\
\text { compared to control } \\
\text { rats. AVG treatment } \\
\text { had no effect in the con- } \\
\text { trol group. In obese rats } \\
\text { treated with AVG, there } \\
\text { was a significant reduc- } \\
\text { tion in glucose, triglyc- } \\
\text { eride, and cholesterol } \\
\text { levels in obese rats giv- } \\
\text { en AVG } 100 \text { mg/kg/day. } \\
\text { AVG at a concentration } \\
\text { of } 200 \text { mg/kg/day re- } \\
\text { stored LDL- and HDL- } \\
\text { C levels in obese rats to } \\
\text { be similar to those in }\end{array}$ \\
\hline
\end{tabular}




aloe vera): diabetic rats,
after 1 week of STZ
administration, were
given Aloe vera 150
mg/kg po) for seven
weeks. Group V (aloe
vera-treated): diabetic
rats, after one week of
STZ administration,
were treated with Aloe
vera (300 mg/kg [dou-
ble group IV] po) for
seven weeks. Group VI
(treated with lisinopril)

the control group.

\section{RESULT}

Based on the literature search, there were 8 studies related to the effect of aloe vera on lipid profile levels, of which there were 7 studies on experimental animals and 1 study on humans. All these journals are international and national journals kwhich are searched from the Database PubMed and Google Scholar by typing the keyword Hypolipidemicand Aloe Vera L. comparison in this study was aloe vera, and the expected outcome was the hypolipidemic effect of aloe vera. which then analyzed using the table for analyzed from tree discussion, results from studies so that know the similarities and differences of these journals(Table2).

\section{DISCUSSION}

Hyperlipidemia is a lipid metabolism disorder characterized by increased levels of total cholesterol, LDL cholesterol, triglycerides, and/or decreased levels of HDL cholesterol. Several risk factors for hyperlipidemia include obesity, diabetes, excessive alcohol consumption, kidney disorders, and drugs. Management of hyperlipidemia consists of nonpharmacological management and the use of lipid-lowering drugs. In addition to conventional therapy, there are also traditional treatments, one of which is by using aloe vera. Glucomannan is a polysaccharide contained in aloe vera. Glucomannan can lower cholesterol and blood sugar levels, lose weight, and affect intestinal activity and immune system function. [9]

Research conducted by Devi (2017) on the Hypolipidemic effect of ethanolic extract of aloe vera (aloe vera 1) on hypercholesterolemic male white rats, the results showed that the results of the Shapiro-Wilk test and Lavene test showed that all data groups were normal and homogeneous. Paired TTest results obtained $\mathrm{p}$-value $=0.000$ 
for both triglycerides, LDL cholesterol, and total cholesterol. Furthermore, the One Way ANOVA parametric test results $\mathrm{p}<0.05$ for the three lipid profiles. LSD test on triglyceride levels in the aqua dest group with $70 \%$ ethanol extract of Aloe vera $\mathrm{L}$ doses of $0.3 \mathrm{~g} / 200 \mathrm{~g}$ BW/day, $\quad 0.6 \mathrm{~g} / 200 \mathrm{~g}$ BW/day, and $1.2 \mathrm{~g} / 200 \mathrm{gBW} /$ day, respectively, $=0.012$, $p=0.000$ and $p=0.000$. LSD test on LDL cholesterol and total cholesterol in the distilled water group with $70 \%$ ethanol extract of Aloe vera L only at a dose of $1.2 \mathrm{~g} / 200 \mathrm{gBW} /$ day which was significantly different with $\mathrm{p}=0.006$ and $\mathrm{p}=0.001$. Ethanol extract of Aloe vera $\mathrm{L}$ dose of $1.2 \mathrm{~g} / 200 \mathrm{gBW} /$ day can reduce lipid profiles in the form of triglyceride levels, LDL cholesterol, and total cholesterol from hypercholesterolemic male white rats. [9]

Research conducted by Prabha Verma (2016) Regarding Hypolipidemic Activity of Aloe Vera in Hyperlipidemic Rats. Research results Aloe vera extract treatment with a dose of $500 \mathrm{mg} / \mathrm{kg} \mathrm{BW}$, caused a decrease in the levels of TC, PL, and TG respectively by 28,25 , and $26 \%$, along with reactivation of PHLA by $22 \%$. Treatment with aloe vera extract for 15 days reversed plasma levels of TC, PL, and TG by 25,21 , and $31 \%$, respectively, along with reactivation of PHLA by $21 \%$. The hypolipidemic action of aloe vera at a dose of $500 \mathrm{mg} / \mathrm{kg} \mathrm{BW}$ is comparable to that of guggulipid at a dose of $200 \mathrm{mg} / \mathrm{kg} \mathrm{BW.} \mathrm{[10]}$

Research conducted by Image (2016) Regarding the Evaluation of The Effects of Aloe Vera Gel Therapy on Alloxan-Induced Diabetes Rats. The results of the lipid profile study showed an increase in the levels of total cholesterol (TC), triglycerides (TG), and low-density lipoprotein (LDL) in the diabetes group that was not treated compared to the normal control group and the group that was treated with Aloe Vera. The AV group showed a decrease in the lipid profile and an increase in HDL levels. [11]

Research conducted by Louay (2019) Regarding the Hypoglycemic and Hypolipidemic Effects of Aloe Vera on Patients with Type 2 Diabetes. Results There was a significant decrease $(p<0.05)$ in the HbA1c values in groups I and II. The reduction was $11.1 \%$ and $25 \%$ in groups I and II respectively and the decrease was not significant $(p<0.05)$ between the subjects of group III. There was a significant decrease $(p \leq 0.05)$ in total cholesterol $6.5 \%$ and $7.11 \%$, triglycerides $10.4 \%$ and $12.6 \%$, Low-Density Lipoprotein (LDL-C) $7.5 \%$ and $11.9 \%$, and a significant increase in High-Density Lipoprotein (HDL-C) $8 \%$ and 25\% was observed in the subjects of groups I and II, respectively. The ratio of LDL-C to HDLC decreased from 3.71 to 3.2 
and 3.9-2.7 in group I and II subjects after the study, respectively. [12]

Research conducted by Autumn (2017) regarding the Hypolipidemic Effects of Aloe Vera Gel Extract on Adult Male Rats Given a High-Fat Diet. The results showed that a high-fat diet significantly increased serum cholesterol, triglycerides, LDL $(\mathrm{p}<0.001)$, and weight gain $(\mathrm{p}<0.01)$ but did not significantly affect serum HDL levels. However, in the group receiving Aloevera gel and a high-fat diet, there was a significant reduction in body weight and serum cholesterol, triglycerides $(\mathrm{p}<0.05)$, and LDL $(\mathrm{p}<0.01)$ levels. [13]

Research conducted by Ramesh (2016) regarding the Comparative Evaluation of Anti-Obesity Effects of Aloe Vera and Gymnema Sylvester Supplementation in Rats Given a C57BL/6J High-Fat Diet. The results of the study at the end of the experimental period, oral administration of both herbs showed a significant reduction $(\mathrm{P}<0.05$ and $\mathrm{P}<0.001)$ in plasma glucose and lipid levels in HFD-fed mice. [14]

Research conducted by Rahoui (2018) Regarding the Beneficial Effects of Aloe Vera Gel on Lipid Profile, Lipase Activity and Oxidant/Antioxidant Status in Obese Rats. The results showed that plasma glucose, cholesterol, and triglyceride levels were significantly higher in obese rats compared to control rats. AVG treatment had no effect in the control group. In obese rats treated with AVG, there was a significant reduction in glucose, triglyceride, and cholesterol levels in obese rats given AVG 100 mg/kg/day. AVG at a concentration of 200 $\mathrm{mg} / \mathrm{kg} /$ day restored LDL- and HDL-C levels in obese rats to be similar to those in the control group.[15]

Research conducted by Mandep (2018) Regarding Diabetes Improvement with aloe vera in rats Induced Diabetic Nephropathy: Implications of Oxidative Stress and Hyperlipidemia. The results showed that treatment with Aloe vera (300 mg/kg/day orally) prevented the development of diabetic nephropathy by lowering the lipid profile, reducing renal oxidative stress, and providing direct renoprotective action. [16]

CONCLUSION
By the background of the
problem and the purpose of the
literature review from several journals,
it can be concluded that there is a
significant relationship between aloe
vera and hyperlipidemia, wherefrom
several studies that have been
previously described
hypolipidemic effect of aloe vera (Aloe
Vera L).

\section{CONFLICT OF INTEREST}

The author declares that there is no conflict of interest in this study. 


\section{FUNDING AND SPONSORSHIP}

This study is self-funded.

\section{ACKNOWLEDGEMENT}

Researchers thank and give appreciation to electronic databases: PubMed and Google Scholar

\section{REFERENCES}

[1] M. A. Toori Et Al., "Prevalence Of Hypercholesterolemia, High LDL, And Low HDL In Iran: A Systematic Review And MetaAnalysis," Iran. J. Med. Sci., Vol. 43, No. 5, Pp. 449-465, 2018.

[2] I. Karam, Y. J. Yang, And J. Y. Li, "Sm Gr Up Sm Atherosclerosis Hyperlipidemia Background And Progress," Sm Atheroscler. J., Vol. 1, No. 1, Pp. 9-15, 2017.

[3] C. F. Lin, Y. H. Chang, S. C. Chien, Y. H. Lin, And H. Y. Yeh, "Epidemiology Of Dyslipidemia In The Asia Pacific Region," Int. J. Gerontol., Vol. 12, No. 1, Pp. 2-6, 2018.

[4] T. G. I. For G. Health, Reducing The Burden of Cardiovascular Disease In Indonesia The George Institute For Global Health. 2017.

[5] U. N. Singh, S. Kumar, And S. Dhakal, "Study Of Oxidative Stress In Hypercholesterolemia," Int. J. Contemp. Med. Res., Vol. 4, No. 5, Pp. 2454-7379, 2017.
[6] G. F. hattat, "A Review Article On Hyperlipidemia: Types, Treatments And New Drug TarTar-

gets,"Biomedpharmajournal.Org, 2014.

[7] M. H. R. P.Laxmipriya, "Evaluation Of Biological Properties And Clinical Effectiveness Of Aloe Vera: A Systematic Review," Www.Sciencedirect.Com, 2015.

[8] And EG Marzanna Hęś, Krzysztof Dziedzic, Corresponding Author, Danuta Górecka, Anna JędrusekGolińska, "Aloe Vera (L.) Webb .: Natural Sources Of Antioxidants A Review,"

Www.Ncbi.Nlm.Nih.Gov, 2015.

[9] DU Rosyidah, YQ Primayanti, And O. Satriyani, "Hypolipidemic Effects of Aloe Vera (Aloe Vera L) Ethanol Extract on Male White Mice with Hypercholesterolemia Model," Biomedika, Vol. 11, No. 1, P. 41, 2019,Doi:10.23917/Biomedika.V11 i1.7662.

[10] E. S. Han And A. Goleman, Daniel; Boyatzis, Richard; Mckee, "Hypolipidemic Activity Of Aloe Vera In Hyperlipidemic Rats," J. Chem. Inf. Model., Vol. 53, No. 9, Pp. 1689-1699, 2019, Doi: 10.13040/Ijpsr.09758232.Ijp.3(4).196-00. 
[11] O. O. Imaga, Ebuehi, O.A.T., Edom, J.J., Obomniru, G.E., And Oyadina, "Evaluation Of The Therapeutic Effects Of Aloe Vera Gel On Alloxan- Induced Diabetic Rats," Vol. 26, No. 2, Pp. 377-386, 2016.

[12] L. Labban And Z. Malek, “The Effects Of Hypoglycemic And Hypolipidemic Properties Of Aloe Vera On Type 2 Diabetics .," Vol. 1, Pp. 1-6, 2019.

[13] L. Labban and Z. Malek, “The Effects of Hypoglycemic and Hypolipidemic Properties of Aloe vera on Type 2 Diabetics .," vol. 1, pp. 1-6, 2019.

[14] R. Pothuraju, R. K. Sharma, S. A. Rather, And S. Singh, "Comparative Evaluation Of Anti-Obesity Effect Of Aloe Vera And Gymnema Sylvestre Supplementation In High-Fat Diet Fed C57bl/6j Mice," J. Intercult. Ethnopharmacol., Vol. 5, No. 4, Pp. 403-407, 2016, Doi: 10.5455/Jice.20160623122710.

[15] W. Rahoui, H. Merzouk, I. A. El Haci, R. Bettioui, R. Azzi, And M. Benali, "Beneficial Effects Of Aloe Vera Gel On Lipid Profile, Lipase Activities And Oxidant/Antioxidant Status In Obese Rats," J. Funct. Foods, Vol. 48, No. April, Pp. 525-532, 2018, Doi: 10.1016/J.Jff.2018.07.050.

[16] M. K. Arora, Y. Sarup, R. Tomar,
M. Singh, And P. Kumar, "Amelioration Of DiabetesInduced Diabetic Nephropathy By Aloe Vera: Implication Of Oxidative Stress And Hyperlipidemia," J. Diet. Suppl., Vol. 16, No. 2, Pp. 227-244, 2019, Doi:0.1080/19390211.2018.1449159 